\title{
THESES IN PROGRESS
}

Alexandra Ault Proof of the Proof: The Printsellers Association and Fine Art Publishing c. 1847-1920

Nicholas Babbington Held to Account: British Caricature and the Financial Discourse of the Late Eighteenth Century

Jacob Badcock Blackness, Technics, and Time: On the Antiblack Materiality of Data

Caitrín Barrett-Donlon Revisioning: Dance, Museums, and Yvonne Rainer

Gabriella Beckhurst Leave No Trace: Environment, Identity, and Affect in Artists' Video, Photography, and Performance, 1970-2008

Helene Engnes Birkeli Landscapes: A Visual History of the Danish West Indies, 1780-1855

Corinna Canali Automating Inquisition: Censorship of Gender and Sexual Expression in Online Content Moderation

Cora Chalaby Control Systems: Helen Frankenthaler, Joan Mitchell, Howardena Pindell, and Alma Thomas's Orderly Abstractions

Edward Christie Beyond Eco Art: Mobilising Post-War (Anti-)Modern Art History Against the Climate Crisis

Daisy Clery Vija Celmins: Measurement and Memory

Tom Cornelius American Surfaces: Topographies of the New West

Ann Coxon New Tapestry: Textile Art in Europe, 1960-1979

Danae Filioti The Relief in Relief: Belatedness in British, Concrete, and Constructive Art 1949-1969

Bea Gassman de Sousa Nigerian Modernism as an African Epistemology

Michael Green Thinking Back: Artistic Returns to H.D.

Glasgow Hardie Uncertain Bodies: The Transient Nature of Colour in Early Modern Italy

Alison Harpur Visual Culture and the Council of Ferrara-Florence (1438-1445) 
Rosalind Hayes 'Look to Your Eating': Animals, Meat, and Visual Culture in Britain, c. 1880-1910

Millie Horton-Insch Race, Gender, and Textiles in Eleventh and Twelfth-Century England

Amber Husain Psychosomatics of Refusal: British Art and Biopower, 1982-1998

Catherine Ingrams Immanent Forms and Latent Creatures: Artistic Networks in Italy, 1947-1958

Chloe Julius Remaking History: The Category 'Jewish' in American Art of the 1990 s

Murad Khan Ontogeny's Exhaust: Noise, Race, and the Individuation of Thought

Talia Kwartler Suzanne Duchamp Does More Intelligent Things Than Paint

Jacqueline Mabey This Must Be the Place: Mapping Artistic Kinship and Economic Change in Downtown New York, 1973-1987

Alice Marinelli The 'Caravaggisti' Problem: Replication, Differentiation, Innovation, and the Function of Religious Painting in the Picture Gallery

Victoria McKenzie A Return to the Soil: An Ecofeminist Re-reading through the Lens of Blackness of Darwinian Evolutionism

Emilia Pearce The Sound of Seventeenth-Century Netherlandish Painting

Domenico Pino Printmaking in the Kingdom of the Two Sicilies (1734-1799)

Manuela Portales Sanfuentes Thinking the Ornament: Collecting, Classifying, and Displaying Decorative Arts in Latin American Museums

Caitlin Powell Cultures of Natality: Rethinking Reproductive Bodies in Weimar Germany

Marina Rovelli Arts of Metals in Milan (1450-1499)

Kalvin Schmidt-Rimpler Dinh Tracing Afrosurrealism, circa 1930-2020

Kimberley Schreiber Photography and the American Carceral State, 1964-1980 
Louis Shankar 'We are Born into a Preinvented Existence' - On the Late Art of David

Wojnarowicz

Tania Sheikhan Through the Lens of Fashion: Politics and Identity in Napoleonic Court, 1804-1815

Petra Sikic Gesture and the Body in Early Modern Italy

Daisy Silver California Modernism: Design Encounters at Mid-Century

Glynnis Stevenson The bleus and the blancs: Political Fractures and the French Revolution at the 1889 Exposition universelle

Cecilia Stinton Embodying Abstraction: The Multimedia Works of Wassily Kandinsky, Natalia Goncharova, and Kurt Schwitters, 1909-1928

Rebecca Van Straten Olivetti: Typing a History of Italian Photography

Helena Vilalta Beyond 'Information': Embodied Conceptualism circa 1970

Vladimir Vilde Comparison of Painting Lining Methods for Historic House Environments

Kitty Whittell Clear Boundaries: Interfaces and Art from 1965-2019

Baylee Woodley Forsaken Femininities: The Long History of Femininity from Medieval to Modern and from Monstrous to Divine

Catrin Wright How We Remember: Renegotiating and Reglobalizing the Memory of the First World War 